\title{
PROSES BERPIKIR SPASIAL PESERTA DIDIK DITINJAU DARI GAYA BELAJAR
}

\author{
Nina Siti Kurniati, Supratman, Sri Tirto Madawistama \\ Universitas Siliwangi, Jln. Siliwangi No. 24, Tasikmalaya 46115, Jawa Barat, Indonesia \\ Email: ninakurniati58@gmail.com
}

\begin{abstract}
Abstrak
Geometri merupakan materi yang dipelajari pada setiap jengjang, tetapi dari hasil penelitian sebelumnya diketahui bahwa terdapat beberapa kesalahan yang dilakukan peserta didik dalam proses penyelesaiannya, oleh karena itu peneliti melakukan penelitian dengan tujuan untuk menganalisis terhadap proses berpikir spasial peserta didik dalam mengkonstruksi pengetahuan baru ditinjau dari gaya belajar. Penelitian ini merupakan penelitian kualitatif dengan metode eksploratif, yaitu peserta didik diberikan kesempatan secara bergantian untuk menyelesaikan masalah sampai ditemukannya subjek penelitian yang sesuai dengan tujuan penelitian. Teknik pengumpulan data dimulai dari pemberian soal berpikir spasial yang telah divalidasi dan dinyatakan layak untuk digunakan, angket gaya belajar yang peneliti adopsi dan melaksanakan wawancara. Peserta didik kelas XI MIPA SMA Negeri 4 Tasikmalaya merupakan subjek penelitian yang dipilih menggunakan eksplorasi. Teknik analisis data yang digunakan yaitu reduksi data, penyajian data, dan penarikan kesimpulan. Hasil penelitian menunjukan bahwa proses berpikir spasial peserta didik dengan gaya belajar visual (S6) konstruksi pengetahuannya didominasi oleh proses asimilasi karena kepekaanya terhadap gambar dan warna yang memudahkannya melakukan visualisasi, baik dengan cara mengkonstruksi atau membayangkan bentuk dari suatu objek geometri yang dipandang dari sudut pandang tertentu, tetapi pada tahap akhir penyelesaiannya ia melakukan kesalahan perhitungan.
\end{abstract}

Kata kunci: geometri, proses berpikir spasial, gaya belajar

\begin{abstract}
Geometry is material that is studied at every level, but from the results of previous studies it is known that there are some mistakes made by students in the process of completion, therefore researchers conduct research with the aims to analyze the spatial thinking processes of students in knowledge new construction in terms learning styles. The research method used qualitative with explorative method, where students are given the opportunity alternately to solve problems until the discovery of research subjects in accordance with the research objectives. Data collection techniques used are starting from giving tests of spatial thinking that had been validated and declared suitable for use, learning style questionnaires that researchers adopted and conducting unstructured interviews. Source of data from this study are students of class XI MIPA SMA Negeri 4 Tasikmalaya, selection of subjects by exploration. Data analiysis used are data reduction, data display and conclusion. The results of this research are that the student with a visual learning style (S6) construction of new knowledge is dominated by the process of assimilation because he's sensitivity to images and colors that make it easy to visualize, either by constructing or imagining the shape of a geometry object viewed from an angle certain viewpoint, but he made a calculation error in the last step.
\end{abstract}

Keywords: geometry, spatial thinking processes, learning styles

\section{Pendahuluan}

Geometri sebagai salah satu materi pelajaran matematika yang dipelajari secara kontinu mulai dari tingkat sekolah dasar hingga sekolah menengah atas, dapat diketahui dari kompetensi-kompetensi dasar pada setiap tingkatan yang berkaitan 
dengan materi geometri [1]. Geometri sebagai materi yang dipelajari disetiap jenjang tidak menjamin bahwa peserta didik tidak melakukan kesalahan dalam proses penyelesaiannya, dari hasil penelitian $[2,3,4]$ bahwa dalam menyelesaikan soal geometri peserta didik melakukan beberapa kesalahan. Kesalahan-kesalahan yang dialami oleh peserta didik tersebut dapat ditelusuri sehingga dapat diusulkan perbaikannya dengan cara menganalisis proses berpikir peserta didik [5]. Aktivitas mental dalam merumuskan dan menyelesaikan masalah serta membuat keputusan dan memahami masalah merupakan bagian dari proses berpikir [6]. Berdasarkan pemaparan tersebut dapat disimpulkan bahwa dengan menganalisis proses berpikir peserta didik dapat kesalahan-kesalahan peserta didik dalam menyelesaikan masalah sehingga dapat diusulkan perbaikannya.

Terdapat beberapa jenis proses berpikir yang dikemukanan oleh ahli, tetapi proses berpikir yang sesuai untuk dianalisis pada materi geometri adalah proses berpikir spasial, karena hasil penelitian yang dilakukan [7] menunjukan bahwa proses berpikir spasial terhadap kemampuan peserta didik dalam menyelesaikan masalah geometri. Selain itu menurut [8] berpikir spasial memiliki peran penting dalam pendidikan, khususnya matematika. Berpikir spasial merupakan kemampuan yang penting dalam memecahkan masalah matematik dalam berbagai konteks [9]. Berdasarkan pemaparan tersebut dapat disimpulkan bahwa proses berpikir spasial sesuai untuk dianalisis pada materi geometri.

Berpikir spasial merupakan aspek mendasar dalam kognitif yang meliputi kemampuan untuk menghasilkan, mengambil, memelihara dan memanipulasi informasi visual-spasial [10]. Berpikir spasial merupakan salah satu bentuk berpikir dan kemampuan kognitif yang unsur-unsurnya terdiri dari konsep ruang, alat representasi dan penalaran [11]. Berpikir spasial berkaitan dengan kemampuan spasial [11]. Kemampuan dalam membayangkan, membandingkan, menduga, menentukan, mengkontruksi, merepresentasikan dan menemukan informasi dari stimulus visual dalam konteks ruang merupakan bagian dari kemampuan spasial matematis [12]. Indikator kemampuan spasial terdiri dari: menyatakan kedudukan antar unsur-unsur suatu bangun ruang, mengidentifikasi dan mengklarifikasi gambar geometri, membayangkan bentuk atau posisi suatu objek geometri yang dipandang dari sudut pandang tertentu, mengkontruksi dan merepresentasikan model-model geometri yang digambar pada bidang datar dalam konteks ruang dan menginvestigasi suatu objek geometri [12].

Terdapat beberapa cara yang dikemukakan oleh ahli untuk menelusuri proses berpikir, dalam penelitian ini penelusurannya berdasarkan proses asimilasi dan akomodasi. Asimilasi dan komodasi merupakan proses konstruktif dalam mengonstruksi pengetahuan baru [13], selain itu berpikir merupakan proses kognitif yang dapat menghasilkan ide atau pengetahuan baru [14]. Konstruksi pengetahuan dalam merupakan hal yang sangat penting, kontrstuksi pengetahuan matematika merupakan suatu proses berpikir matematika yang dapat diperoleh dari berbagai masalah [15]. Apabila peserta didik mampu mengintegrasikan persepsi, konsep atau pengalaman baru kedalam skema yang telah ada dalam pikirannya disebut proses 
asimilasi, apabila terjadi ketidak sesuaian peserta didik akan mengalami proses akomodasi yaitu kondisi dimana peserta didik tidak mampu mengintegrasikan persepsi, konsep atau pengalaman baru kedalam skema yang telah ada dalam pikirannya, hal tersebut terjadi melalui: (1) membentuk skema baru yang dapat sesuai dengan rangsangan yang benar, atau (2) memodifikasi skema yang ada sehingga sesuai [16]. Asimilasi merupakan proses dimana menggabungkan stimulus ke dalam skema yang telah ada, sedangkan akomodasi merupakan proses penyesuaian skema lama atau menbangun skema baru karena skema lama tidak dapat menyesuaikan dengan skema subjek [17].

Salah satu faktor yang mempengaruhi kemampuan peserta didik dalam menyelesaikan masalah matematik adalah gaya belajarnya [18]. Hal tersebut didukung pula oleh hasil penelitian yang dilakukan [19] yang menunjukan bahwa gaya belajar peserta didik berpengaruh terhadap kemampuan spasialnya. Terdapat tiga tipe gaya belajar yaitu visual, auditori dan kinestetik [20]. Peserta didik dengan gaya belajar visual modalitas belajarnya mengandalakan indera penglihatan, peserta didik dengan gaya belajar auditori modalitas belajarnya mengandalkan indera pendengaran sedangkan peserta didik dengan gaya belajar kinestetik modalitas belajarnya dengan mengakses segala jenis gerak dan emosi [21]. Berdasarkan uraian tersebut tujuan dari penelitian ini untuk menganalisis proses berpikir spasial peserta didik dalam mengkonstruksi pengetahuan baru ditinjau dari gaya belajar merupakan tujuan dari penelitian ini.

\section{Metode}

Penelitian ini merupakan penelitian kualitatif, dengan metode eksploratif. Metode penelitian eksploratif merupakan metode penelitian di mana peserta didik diberikan kesempatan secara bergantian untuk menyelesaikan masalah sampai ditemukannya subjek yang sesuai dengan tujuan penelitian [22]. Eksplorasi dalam penelitian dilakukan kepada peserta didik sampai ditemukannya subjek penelitian dengan kriteria memenuhi tiga unsur dan lima indikator proses berpikir spasial dalam mengkonstruksi pengetahuan baru serta komunikatif dalam memberikan informasi mengenai proses pekerjaannya.

\subsection{Subjek Penelitian}

Peserta didik kelas XI MIPA merupakan subjek penelitian yang dipilih menggunakan eksplorasi. Eksplorasi merupakan teknik untuk menemukan sesuatu yang belum diketahui [23]. Subjek dalam penelitian ini yaitu peserta didik dengan kriteria memenuhi tiga unsur dan lima indikator proses berpikir spasial dalam mengkonstruksi pengetahuan baru untuk setiap kategori gaya belajar serta komunikatif dalam memberikan informasi mengenai proses pekerjaannya sehingga peneliti mendapatkan informasi dari sumber data yang tersedia sampai data jenuh. 


\subsection{Pengumpulan Data}

Pemberian soal berpikir spasial, angket gaya belajar dan melaksanakan wawancara tidak terstruktur merupakan teknik penyumpulan data dalam penelitian. Instrumen yang digunakan adalah peneliti sebagai instrumen kunci, untuk menghindari subjektivitas yang dapat mengakibatkan data dari hasil penelitian bias, maka dalam penelitian ini peneliti berperan sebagai perencana, pengumpul data, penganalisis dan pengolah data. Instrumen pendukung dalam penelitian ini yaitu soal berpikir spasial yang telah divalidasi dan dinyatakan layak untuk digunakan, angket gaya belajar yang peneliti adopsi dan pedoman wawancara berupa garis besar dari pertanyaan yang akan diajukan dan dapat berkembang sesuai dengan respon peserta didik.

\subsection{Analisis Data}

Reduksi data, penyajian data, dan verifikasi merupakan teknik analisis data Miles dan Huberman yang digunakan. Proses analisis dilakukan secara interaktif dan berlangsung secara terus menerus sampai tuntas, sehingga datanya sudah jenuh [24]. Aktivitas dalam menganalisis dikatakan tuntas dan datanya jenuh apabila telah ditemukannya peserta didik yang menjadi subjek penelitian yang memenuhi kriteria.

\section{Hasil dan Diskusi}

\subsection{Hasil Penelitian}

Penelitian dilaksanakan pada tanggal 10 Februari - 05 Maret 2020 kepada sepuluh peserta didik kelas XI MIPA. Hasil pengisian angket gaya belajar diketahui bahwa sepuluh peserta didik terbagi kedalam tiga kecenderungan gaya belajar, gaya belajar visual (S2, S5, S6 dan S8), gaya belajar auditori yaitu S9 serta gaya belajar kinestetik (S1, S3, S4, S7 dan S10). Peneliti mengambil satu peserta didik (S6) untuk dianalisis proses berpikir spasialnya dalam mengkonstruksi pengetahuan baru. S6 dipilih sebagai subjek penelitian karena dalam penyelesaian soal berpikir spasial memenuhi tiga unsur dan lima indikator dalam proses berpikir spasialnya serta komunikatif dalam memberikan informasi berkaitan dengan proses penyelesaian yang dilakukanya. Alasan lain S6 yang merupakan peserta didik dengan gaya belajar visual dipilih sebagai sabjek penelitian karena mampu mengoptimalkan kepekaannya terhadap warna dan gambar dalam proses penyelesaian soal berpikir spasial, sehingga mampu menggunakan strategi yang tepat dalam proses penyelesaiannya. Hasil proses penyelesaian soal berpikir spasial dan hasil wawancara terhadap S6 dengan kategori gaya belajar visual, diperoleh alur proses berpikir spasialnya sebagai berikut. 


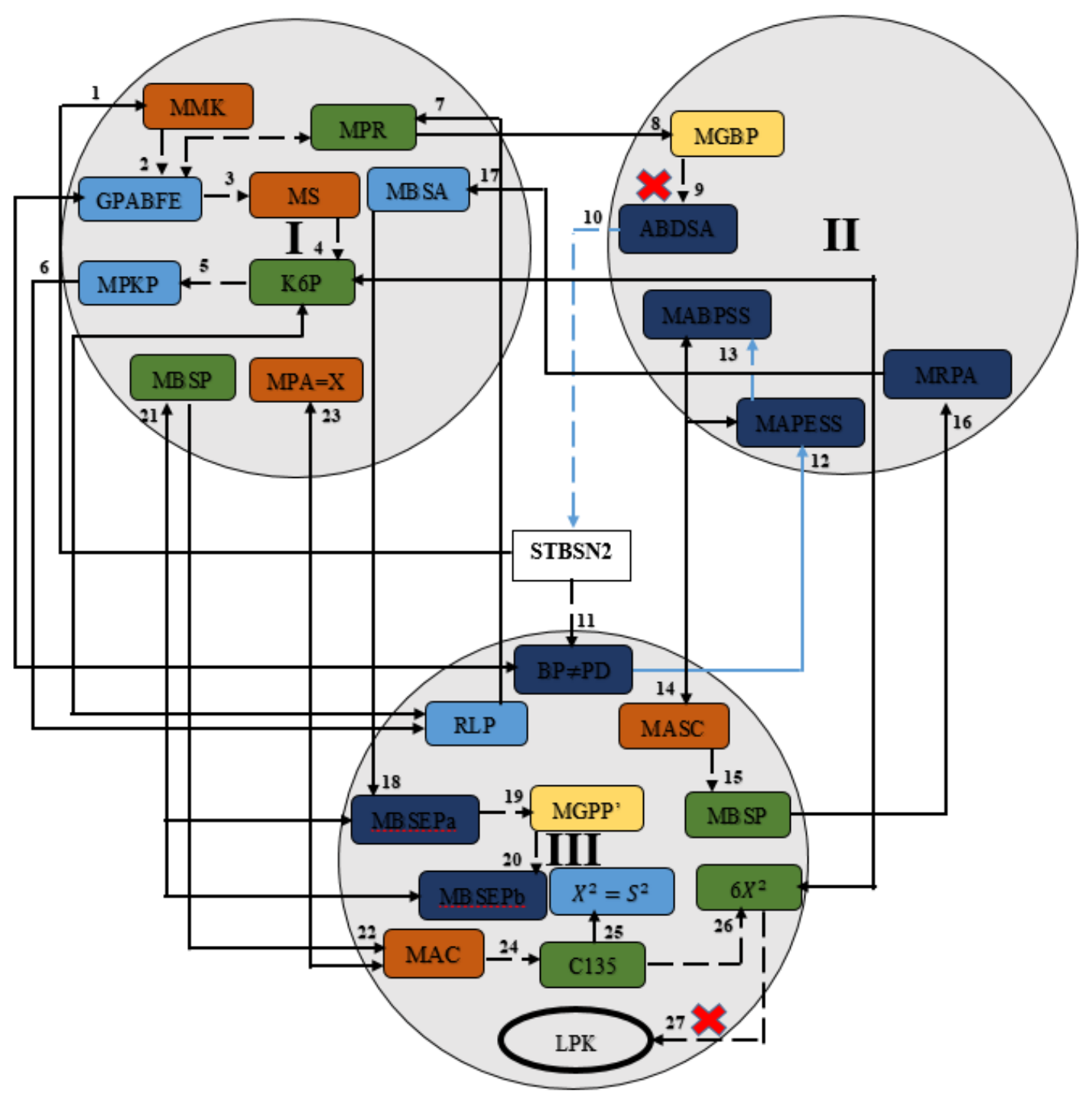

Gambar 1. Alur Proses Berpikir Spasial S6

Adapun keterangan Gambar 1 terkait grafik dan pengkodean dalam penyelesaian soal berpikir spasial nomor dua untuk S6 pada Tabel 1 dan Tabel 2 sebagai berikut.

Tabel 1. Keterangan Grafik Penyelesaian S6

\begin{tabular}{|c|l|}
\hline Kode Grafik & \multicolumn{1}{c|}{ Keterangan } \\
\hline & Soal \\
\hline ( & Unsur berpikir spasial (Konsep Ruang) \\
\hline
\end{tabular}

JARME, Volume 3, No.1, Januari 2021, 22 - 33. 


\begin{tabular}{|c|c|}
\hline Kode Grafik & Keterangan \\
\hline & Unsur berpikir spasial (Alat Representasi) \\
\hline & Unsur berpikir spasial (Penalaran) \\
\hline & $\begin{array}{l}\text { Indikator kemampuan spasial (Menyatakan kedudukan antar unsur-unsur } \\
\text { bangun ruang) }\end{array}$ \\
\hline & $\begin{array}{l}\text { Indikator kemampuan spasial (Mengidentifikasi dan mengklarifikasi gambar } \\
\text { geometri) }\end{array}$ \\
\hline & $\begin{array}{l}\text { Indikator kemampuan spasial (Membayangkan bentuk atau posisi suatu objek } \\
\text { geometri yang dipandang dari sudut pandang tertentu) }\end{array}$ \\
\hline & $\begin{array}{l}\text { Indikator kemampuan spasial (Mengkonstruksi dan merepresentasikan } \\
\text { model-model geometri yang digambar pada bidang datar dalam konteks } \\
\text { ruang) }\end{array}$ \\
\hline & Indikator kemampuan spasial (Menginvestigasi suatu objek geometri) \\
\hline & Hasil Akhir Equilibrium \\
\hline & Hasil Akhir Disequilibrium \\
\hline & Stak \\
\hline & Arah yang menunjukan unsur proses berpikir spasial (Asimilasi) \\
\hline & Arah yang menunjukan unsur proses berpikir spasial (Akomodasi) \\
\hline & $\begin{array}{l}\text { Arah yang menunjukan keterkaitan antar unsur proses berpikir spasial } \\
\text { (Asimilasi) }\end{array}$ \\
\hline 4 & $\begin{array}{l}\text { Arah yang menunjukan keterkaitan antar unsur proses berpikir spasial } \\
\text { (Akomodasi) }\end{array}$ \\
\hline$----\rightarrow$ & Arah yang menunjukan indikator kemampuan spasial (Asimilasi) \\
\hline$----\rightarrow$ & Arah yang menunjukan indikator kemampuan spasial (Akomodasi) \\
\hline$\leftarrow--ー-\triangleright$ & $\begin{array}{l}\text { Arah yang menunjukan saling keterkaitan antar indikator kemampuan spasial } \\
\text { (Asimilasi) }\end{array}$ \\
\hline$\leftarrow--ー-\triangleright$ & $\begin{array}{l}\text { Arah yang menunjukan saling keterkaitan antar indikator kemampuan spasial } \\
\text { (Akomodasi) }\end{array}$ \\
\hline
\end{tabular}

Tabel 2. Keterangan Pengkodean Penyelesaian S6

\begin{tabular}{|l|l|}
\hline \multicolumn{1}{|c|}{ Kode Grafik } & \multicolumn{1}{c|}{ Keterangan } \\
\hline STBSN2 & Soal berpikir spasial \\
\hline MMK & Mengidentifikasi dan mengklarifikasi kubus pada soal \\
\hline GPABFE & Garis yang melewati P berada pada bidang ABFE \\
\hline MS & Memahami soal (diketahui dan ditanyakan) \\
\hline K6P & Menyatakan kubusnya terdiri dari 6 permukaan \\
\hline MPKP & Menyatakan permukaannya persegi \\
\hline RLP & Rumus luas permukaannya $(6 \times P \times L)$ \\
\hline MPR & Mencari panjang rusuk kubus \\
\hline MGBP & Membuat garis bantu pada titik P \\
\hline ABDSA & Segitiga ABD siku-siku di A \\
\hline BP $\neq$ PD & Garis BP tidak segaris dengan PD \\
\hline MAPESS & Menyatakan APE merupakan segitiga sembarang \\
\hline
\end{tabular}




\begin{tabular}{|c|c|}
\hline Kode Grafik & Keterangan \\
\hline MABPSS & Menyatakan ABP merupakan segitiga sembarang \\
\hline MASC & Menggunakan aturan sinus cosinus (segitiga sembarang) \\
\hline MBSP & Mencari besar sudut $\mathrm{P}$ \\
\hline MRPA & Melakukan rotasi bidang ABFE pusat dititik A \\
\hline MBSA & Menyatakan besar sudut A $90^{\circ}$ \\
\hline MBSPa & Menyatakan besar sudut $\mathrm{Pa} 45^{\circ}$ (segitiga siku-siku dan sama kaki) \\
\hline MGPP' & Membuat garis bantu PP' \\
\hline $\mathrm{MBSPb}$ & Menyatakan besar sudut $\mathrm{Pb} 90^{\circ}$ (segitiga siku siku dan sama kaki) \\
\hline MBSP & Menyatakan besar sudut P $135^{\circ}\left(45^{\circ}+90^{\circ}\right)$ \\
\hline MAC & Menggunakan aturan cosinus $a^{2}=b^{2}+c^{2}-2 b c \cdot \cos \alpha$ (segitiga sembarang) \\
\hline $\mathrm{MPA}=\mathrm{X}$ & Menyatakan panjang A=X (rusuk kubus) \\
\hline C135 & $\operatorname{Cos} 135^{\circ}=\operatorname{Cos} 45^{\circ}=-\frac{1}{2} \sqrt{2}($ dikuadran 2$)$ \\
\hline$X^{2}=S^{2}$ & $X^{2}$ sama dengan luas satu permukaan kubus $S^{2}$ \\
\hline $6 X^{2}$ & Luas satu permukaan kubus dikalikan enam \\
\hline LPK & Luas permukaan kubus $64+12 \sqrt{34}$ \\
\hline
\end{tabular}

Berdasarkan Gambar 1 terlihat proses penyelesaian soal berpikir spasial yang dilakukan S6 meliputi tiga unsur serta lima indikator kemampuan spasial. Pada unsur yang pertama yaitu konsep ruang S6 memenuhi tiga indikator kemampuan spasial yaitu menyatakan kedudukan antar unsur-unsur suatu bangun ruang, mengidentifikasi dan mengklarifikasi gambar geometri dan menginvestigasi suatu objek geometri. Pada unsur yang kedua yaitu alat representasi yang memenuhi dua indikator kemampuan spasial yaitu membayangkan bentuk atau posisi suatu objek geometri yang dipandang dari sudut pandang tertentu serta mengkontruksi dan merepresentasikan model-model geometri yang digambar pada bidang datar dalam konteks ruang. Pada unsur yang ketiga yaitu penalaran memenuhi kelima indikator kemampuan spasial. Dari Gambar 1 diketahui S6 mengalami kendala dalam menentukan panjang rusuk kubus pada langkah awal penyelesaiannya, tetapi ia kemudian mampu mengintegrasikan persepsi, konsep atau pengalaman baru kedalam skema yang telah ada dalam pikirannya, hanya dalam proses perhitungan ditahap akhir ia melakukan kesalahan.

Berdasarkan Gambar 1, sesuai dengan keterangan yang disajikan pada Tabel 1 dan Tabel 2 diketahui langkah awal yang dilakukan S6 dalam menyelesaikan soal berpikir spasial dimulai dari mengidentifikasi dan mengklarifikasi kubus pada soal tersebut (MMK), ia menyatakan bahwa pada kubus tersebut terdapat garis yang melewati titik P pada bidang ABFE (GPABFE). S6 memahami apa yang diketahui dan ditanyakan pada soal (MA) dimana ia harus mencari luas permukaan kubus yang permukaannya terdiri dari 6 (K6P). Permukaan kubus tersebut berbentuk persegi (MPKP), sehingga rumus yang ia gunakan adalah $6 \times P \times L$ (RLP). Langkah berikutnya adalah mencari panjang rusuk kubusnya yang menjadi kunci dari penyelesaian soal tersebut (MPR), untuk itu S6 membuat garis bantu pada titik P (MGBP) dan menyatakan bahwa segitiga ABD siku-siku di A (ABDSA), tetapi setelah S6 amati lebih lanjut ia menyatakan bahwa garis $\mathrm{BP}$ dan $\mathrm{PD}$ tidak segaris $(\mathrm{BP} \neq \mathrm{PD})$. S6 menyatakan ada cara lain untuk menentukan panjang rusuknya, tetapi ada komponen yang harus dicari terlebih dahulu karena APE dan ABP merupakan segitiga sembarang (MAPESS), 
(MABPSS) yaitu dengan menggunakan aturan cosinus (MASC) serta harus menentukan terlebih dahulu besar sudut Pnya (MBSP).

Strategi yang S6 lakukan adalah dengan melakukan rotasi pada bidang ABFE yang pusatnya di A (MRPA), ia mengidentifikasi bahwa besar sudut A yaitu $90^{\circ}$ (MRPA), sehingga besar sudut $\mathrm{Pa} 45^{\circ}$ karena selain segitiga siku-siku juga merupakan segitiga sama kaki (MBSPa). S6 membuat garis bantu yang menghubungkan titik P ke P' (MGPP'), ia mengidentifikasi bahwa segitiga yang terbentuk merupakan segitiga siku-siku dan sama kaki sehingga besar sudut $\mathrm{Pb} 90^{\circ}$ (MBSPb). S6 setelah kedua besar sudutnya diketahui ia menyatakan bahwa besar sudut $\mathrm{P} 135^{\circ}$ yang diperoleh dari hasil penjumlahan besar sudur Pa dan Pb (MBPS). S6 setelah semua komponen diperoleh, ia menggunakan aturan cosinus karena segitiga APE merupakan segitiga sembarang (MAC). S6 menyatakan bahwa panjang A merupakan panjang rusuk kubusnya $(M P A=X)$ dan $\operatorname{Cos} 135^{\circ}=\operatorname{Cos} 45^{\circ}$ dikuadran dua yaitu $-\frac{1}{2} \sqrt{2}$ (C135). S6 pada saat melakukan perhitungan menyatakan bahwa $X^{2}$ sama dengan luas satu permukaan kubus $S^{2}\left(X^{2}=S^{2}\right)$, setelah ia mengetahui luas satu permukaannya untuk mejawab soal nomor dua ia melakukan operasi perkalian untuk mengetahui luas permukaan kubusnya $\left(6 X^{2}\right)$. Hasil perhitungan akhirnya ia menyatakan bahwa luas permukaan kubusnya adalah $64+12 \sqrt{34}$ (LPK), pada saat perhitungan akhir ini S6 mengalami kesalahan dalam menentukan hasil akhirnya.

\subsection{Diskusi}

Hasil pengkategorian gaya belajar S6 termasuk kedalam gaya belajar visual. Karakteristik dari peserta didik dengan gaya belajar visual mereka fokus terhadap gambar dan warna [25]. S6 dalam menyelesaikan soal berpikir spasial mampu memecahkan masalah dengan melibatkan pengalaman sebelumnya yang diperoleh dengan cara menggali informasi-informasi yang telah tersimpan untuk menyusun strategi dalam menyelesaikan soal berpikir spasial berkaitan dengan luas permukaan. Hasil akhir yang diperoleh dalam menyelesaikan soal berpikir spasial S6 melakukan kesalahan perhitungan pada langkah terakhir sehingga jawaban yang diperolehnya tidak tepat sehingga S6 berada dalam kondisi disequilibrium. Proses penyelesaian soal berpikir spasial S6 mengkonstruksi pengetahuan baru dengan cara mengintegrasikan persepsi, konsep atau pengalaman baru kedalam skema yang telah ada dalam pikirannya pada setiap proses penyelesaiannya, sehingga dalam penyelesaiannya S6 melalui proses asimilasi dan akomodasi.

Langkah awal yang dilakukan S6 untuk menyelesaikan soal berpikir spasial adalah mengidentifikasi dan mengklarifikasi gambar kubus pada soal termasuk komponen-komponennya sehingga mengarah pada startegi penyelesaiannya yang berkaitan dengan luas permukaan kubus. S6 mengidentifikasi bahwa kubus tersebut terdiri dari enam permukaan yang berbentuk persegi serta titik P yang berada pada bidang ABFE. Hal ini didukung oleh [26] kemampuan imajinasi yang baik mempengaruhi kemampuan dalam menganalisis masalah. Konstruksi pengetahuan baru yang dialami S6 dalam proses penyelesaiannya disibut asimilasi. S6 pada langkah tersebut memenuhi unsur proses berpikir spasial yaitu konsep ruang dimana ia 
mampu menyatakan kedudukan antar unsur, mengidentifikasi dan menginvestigasi dengan tepat.

Langkah berikutnya yang S6 lakukan adalah membuat garis bantu dititik P untuk menentukan panjang rusuk kubusnya tetapi posisi titik $\mathrm{P}$ dengan garis bantunya terletak pada bidang yang berbeda, sehingga konsep yang S6 rencanakan tidak dapat digunakan. Kondisi yang S6 alami disebut disequilibrium. S6 kemudian melakukan analisis terhadap segitiga-segitiga yang terbentuk pada bidang ABFE sebagai segitiga sembarang yang mengarah pada strategi penyelesaian untuk menentukan panjang rusuknya. S6 dengan melakukan rotasi bidang ABFE yang pusatnya di A untuk memperoleh data mengenai besar sudut pada segitiga sembarang tersebut. Hal ini didukung oleh [27] bahwa keterampilan dalam memahami rotasi objek geometri baik dari bentuk 2-D dan 3-D secara cepat dan akurat akan berpengaruh tergadap kemampuan spasialnya. Proses konstruksi pengetahaun baru yang dilakukan S6 untuk memperoleh besar sudut dengan tepat hingga mencapai kondisi equilibrium. S6 pada langkah tersebut memenuhi unsur proses berpikir spasial yaitu alat representasi dimana ia mampu mengkonstruksi dan membayangkan gambar dengan tepat.

Hasil rotasi yang dilakukan pada bidang ABFE S6 dapat menggidentifikasi unsurunsur yang diperlukan untuk memperoleh hasil akhir berupa luas permukaan kubusnya. Adapun unsur-unsur yang dapat diidentifikasi diantaranya besar sudut, luas satu permukaan kubus. Menurut [28] analisis merupakan sifat dari proses berpikir dalam penalaran, dimana informasi yang terdiri dari objek dan keterkaitan antar objek spasial melalui pengamatan dan identifikasi harus dianalisis terlebih dahulu. Hasil akhir yang diperoleh S6 berkaitan dengan luas permukaan kubusnya tidak tepat, dimana S6 dalam proses perhitungan tahap akhir ia melakukan kesalahan. Hal tersebut sesuai dengan penelitian yang dilakukan [29] bahwa kesalahan yang dilakukan oleh peserta didik dengan gaya belajar visual adalah kesalahan dalam perhitungan untuk menyelesaikan masalah pada tahap akhir. S6 pada langkah tersebut memenuhi unsur proses berpikir spasial yaitu penalaran dimana ia mampu mengumpulkan informasi dari hasil pengamatan tetapi dalam proses perhitungan S6 melakukan kesalahan sehingga hasil akhir yang diperoleh tidak tepat. S6 pada langkah tersebut memenuhi unsur proses berpikir spasial yaitu penalaran dimana ia mampu mengumpulkan informasi dari hasil pengamatan untuk menghasilkan kesimpulan tetapi dengan perhitungan yang tidak cermat sehingga kesimpulan yang dihasilkan tidak valid.

Hasil analisis terhadap penyelesaian yang dilakukan dan hasil wawancara S6 yang memiliki gaya belajar visual menggunakan strategi penyelesaian dengan penggunaan konsep secara tepat. Hal tersebut didukung oleh kemampuan mengkonstruksi dan membayangkan objek geometri yang dipandang dari sudut pandang tertentu dengan tepat, sesuai dengan karakter dari peserta didik dengan gaya belajar visual dimana mereka memiliki tingkat imajinasi yang tinggi dalam berpikir dan memvisualisasikan [30]. Kemampuan memvisualisasikan dan membayangkan yang dimiliki S6 dengan gaya belajar visual akan mendukung dalam proses menyatakan kedudukan antar unsur, mengidentifikasi dan mengklarifikasi serta

JARME, Volume 3, No.1, Januari 2021, 22 - 33. 
menginvestigasi objek geometri yang dilakukan sehingga S6 mampu menentukan strategi mengatasi kendala yang dihadapi dalam proses penyelesaian soal nomor satu dan soal nomor dua dengan tepat. [31] representasi visual mampu meningkatkan kemampuan peserta didik dalam memperoleh informasi dan menentukan strategi dengan cara mengingat, memahami serta menghubungkan fakta serta konsep. Hasil akhir yang dilakukan S6 pada soal nomor satu memperoleh jawaban yang tepat, tetapi untuk soal nomor dua ia melakukan kesalahan dalam melakukan perhitungan pada tahap akhir yaitu menentukan luas permukaan kubusnya. Sesuai dengan hasil penelitian yang dilakukan [29] bahwa kesalahan yang dilakukan oleh peserta didik dengan gaya belajar visual adalah kesalahan dalam perhitungan untuk menyelesaikan masalah pada tahap akhir.

\section{Simpulan}

Proses berpikir spasial S6 dengan kategori gaya belajar visual konstruksi pengetahuan barunya didominasi oleh proses asimilasi. Hal tersebut terjadi karena kepekaanya terhadap gambar dan warna yang memudahkannya melakukan visualisasi, baik dengan cara mengkonstruksi atau dengan membayangkan bentuk dari suatu objek geometri yang dipandang dari sudut pandang tertentu. Visualisasi yang dilakukannya menunjang dalam hal menyatakan kedudukan antar unsur, mengidentifikasi dan mengklarifikasi serta menginvestigasi objek geometri yang dilakukan sehingga mampu menentukan strategi penyelesaian dengan tepat, tetapi pada tahap akhir penyelesaian soal berpikir spasial S6 tidak cermat dalam melakukan perhitungan sehingga jawaban yang diperolehnya tidak tepat.

\section{Referensi}

[1] Kementerian Pendidikan dan Kebudayaan 2018 Peraturan menteri pendidikan dan kebudayaan 37 tentang kompetensi inti dan kompetensi dasar

[2] Roskawati, Ikhsan M \& Juandi D 2015 Analisis penguasaan siswa sekolah menengah atas pada materi geometri Jurnal Didaktik Matematika 2(1) 6470

[3] Sidik M J, Hendriana H \& Sariningsih R 2018 Analisis kesalahan siswa SMP kelas XI pada materi bangun ruang sisi datar saat menyelesaikan soal berpikir kritis Jurnal Pembelajaran Matematika Inovatif 1(5)

[4] Utami D N, Kusmanto B \& Widodo S A 2019 Analisis kesalahan dalam mengerjakan soal geometri Jurnal Edukasi Matematika dan Sains 7(1) 37-44

[5] Wardhani W A, Subanji S \& Dwiyana D 2016 Proses Berpikir Siswa Berdasarkan Kerangka Kerja Mason Jurnal Pendidikan: Teori Penelitian dan Pengembangan 1(3) 297-313

[6] Ariefia H E, As'ari A R \& Susanto H 2016 Proses berpikir siswa dalam menyelesaikan permasalahan pada materi trigonometri Jurnal pembelajaran matematika

[7] Tikhomirova T 2017 Spatial thinking and memory in Russian high school students with different levels of mathematical fluency Elsevier 237 12601264 doi: $10.1016 /$ j.sbspro.2017.02.204.

[8] Cheng Y L \& Mix K S 2015 Spatial training improves children's mathematics ability. Journal of Cognition and Develovment 15(1) 2-11 
[9] Minori M 2011 Effectiveness of Digital Educational Materials For Developing Spatial Thinking of Elementary School Student Elsevier 21 116-119 doi:10.1016/j.sbspro.2011.07.045.

[10] Hawesn Z, Moss J, Caswell B \& Poliszczuk D 2015 Effects of metal retation training on children's spatial and mathematics performance: a randomized controlled study Elsevier 4 60-68

[11] National Research Council 2006 Learning to Think Spatially: GIS as a Support System in the K-12 Curriculum (Washington, DC: National Academies Pres)

[12] Sugiarni R, Alghifari E \& Ifanda A R 2018 Meningkatkan kemampuan spasial matematis siswa dengan model pembelajaran problem based learning berbantuan geogebra Jurnal Pendidikan Matematika 3(1) 93-102

[13] Setyawan D \& Rahman A 2013 Eksplorasi proses kontruksi pengetahuan matematika berdasarkan gaya berpikir Jurnal Sainsmat 11(2) 140-152

[14] Ariefia H E, As'ari A R \& Susanto H 2016 Proses berpikir siswa dalam menyelesaikan permasalahan pada materi trigonometri Jurnal pembelajaran matematika

[15] Fatimah A T, Aman A \& Effendi A 2017 Kontrstruksi pengetahuan trigonometri kelas X melalui geogebra dan LKPD Jurnal Nasional Pendidikan Matematika 1(2) 178-188

[16] Yogi A 2018 Proses asimilasi dan akomodasi mahasiswa bergaya kognitif field independent dalam menyelesaikan masalah geometri Prosiding Seminar Nasional 4(1) 394-404

[17] Zhiqing Z 2015 Assimilation, accommodation, and equilibration: a schema-based perpective on translation as process and as product International Forum of Teaching and Studies 11(1-2) 84-89

[18] Makhlouf, Martinez \& Dahawy 2012 A Comparison of Preferred Learning Styles between Vocational and Academic Secondary School Students in Egypt Institute for Learning Styles Journal 5-1

[19] Siregar B H, Siahaan C Y \& Hariyanti H 2018 Peningkatan kemampuan spasial melalui penerapan teori an Hiele terintegrasi dengan multimedia dengan mempertimbangkan gaya belajar siswa Jurnal Handayani PGSD FIP Unimed 9(2) $62-71$

[20] De Porter B \& Hernacki M 2016 Quantum learning: membiasakan belajar nyaman dan menyenangkan (Bandung Indonesia: Penerbit Kaifa PT Mizan Pustaka)

[21] Gunawan W A 2012 Genius learning strategy: Petunjuk praktis untuk menggunakan accelerated learning (Jakarta, Indonesia: Penerbit Gramedia Pustaka Utama)

[22] Supratman 2019 The role of conjecturing via analogical reasoning in solving problem based on Piaget's theory Journal of Physics: Conference Series 1157(3)

[23] Sugiyono 2016 Metode penelitian kuantitatif, kualitatif dan R\&D (Bandung Indonesia: Penerbit Alfabeta)

[24] Sugiyono 2017 Metode penelitian kombinasi mixed method (Bandung Indonesia: Penerbit Alfabeta)

[25] Sword L K \& Director G 2005 The Power Of Visual Thinking (Gifted \& Creative Services Australia)

[26] Muljo A 2018 Korelasi kecerdasan visual spasial dan kecerdasan logis matematis dengan kemampuan berpikir kreatif di SMA Negeri 1 kejuruan muda Vicratina: Jurnal Pendidikan Islam 2(2) 47-56 
[27] Nagy-Kondor R 2017 Spatial Ability: Measurement And Development In VisualSpatial Ability In STEM Education (Springer: Cham)

[28] Kho R 2016 Penjenjangan penalaran visuospasial siswa dalam menyelesaikan masalah geometri Seminar Nasional 1(1)

[29] Salido A \& Dasari D 2019 Students' errors in solving probability problems viewed by learning style Journal of Physics: Conference Series 1211 (1)

[30] Rajapakshe W 2018 Investigation of learning style preferences of buseness students in Saudi Arabia-using VAK assessment model Global Journal of Management and Business Research: a Administration and Management 18(11)

[31] Solihatin E \& Syahria Z 2019 The effects of Brain-Based Learning and ProjectBased Learning strategies on student group mathematics learning outcomes student visual learning styles Pedagogical Research 4(4) 